\title{
An Evaluation of Dimension Analysis for Predicting Shrub Biomass
}

\author{
ROBERT B. MURRAY AND M. QUINN JACOBSON
}

\begin{abstract}
Fifteen independent variables consisting of circumference, surface area, and volume for various assumed shapes were derived from simple diameter and height measurements. These variables were used in seven models to predict aboveground biomass of leaves, different sizes of live and dead twigs, and combinations of fractions for threetip sagebrush, gray horsebrush, green rabbitbrush, and broom snakeweed. In addition, models based on height and circumference were tested on each species and fraction. $A$ simple linear model with surface area or volume as independent variables and height $\times$ circumference models gave the best biomass predictions for these species.
\end{abstract}

Land managers and researchers require reliable estimates of shrub weights to assess site productivity, food abundance, treatment effects, and fuel loading. With increased emphasis on prescription burning to improve range shrublands, techniques are needed to rapidly determine the weight of various live and dead plant fractions. Established techniques, such as harvesting, are slow and expensive. Uresk et al. (1977) estimated that clipping big sagebrush (Artemisia tridentata) phytomass was 120 times more expensive than using dimension analysis. Using the weight estimate technique (Pechanec and Pickford 1937) requires a considerable training and clipping to check estimates. A technique that is rapid, relatively accurate, and requires little training is desirable.

Tufts (1919) found a high correlation between trunk circumference and weight of the top of fruit trees. Since this early beginning, many others including Kittredge (1944), Attiwill (1962), Baskerville (1965), and Brown (1978) have used combinations of trunk diameter, total height, live crown length, ratios of live crown length to total height, and crown widths to estimate tree biomass. In most cases, very successful relationships were developed from these simple measurements.

Similarly, biomass estimates of various shrub species and plant fractions have been developed using stem diameters (Telfer 1969, Brown 1976), crown diameter axes (Rittenhouse and Sneva 1977), crown volume (Chew and Chew 1965, Lyon 1968, Mack 1971, Burk and Dick-Peddie 1973, Ludwig et al. 1975, Rittenhouse and Sneva 1977, and Wakimoto and Menke 1978), crown cover (Ludwig et al. 1975), and height $\times$ circumference (Harniss and Murray 1976) as independent variables. Various crown shapes have been assumed. Most models were of the form $Y=a+b X, Y=a X^{b}$, or $Y$ $=a+b X_{1}+c X_{2}$. Harniss and Murray (1976) found that the model $Y=a H C^{b}$ predicted leaf biomass of big sagebrush quite well.

A large number of variables could be used to predict biomass. However, variables that express the size of the crown appear to be most useful. We sought a technique that was rapid, easy to use in the field, and produced reliable results. Therefore, our objectives were: (1) to develop equations for biomass prediction that were based on easily measured crown diameters and height, (2) to compare different shapes and their circumferences, surface areas, and volumes calculated from the measurements in (1), (3) to monitor plant size and dead to live ratio per plant, parameters that are useful in predicting rate of fire spread, and (4) to test easily com-

\footnotetext{
Authors are range scientist, USDA Agr. Res. Serv., U.S. Sheep Exp. Sta., Dubois Ida. 83423; and range management specialist, University of Idaho, U.S. Sheep Exp. Sta., Dubois, Id. 83423.

Manuscript received January 7, 1981.
}

puted regression models. Four species common to sagebrush rangeland were selected for study: threetip sagebrush ( $A$. tripartita: gray horsebrush (Tetradymia canescens); green rabbitbrush (Chrysothamnus viscidiflorus); and broom snakeweed (Gutierrezia sarothrae).

\section{Study Area and Methods}

The U.S. Sheep Experiment Station consists of ( 10360 ha $) 25600$ acres of sagebrush-grass rangeland located in Clark County, (90 km) $56 \mathrm{mi}$ north of Idaho Falls, Ida. The area is used annually as spring-fall range for sheep. Vegetation is predominantly shrubs with an understory of perennial grasses and forbs. All sites from which shrubs were measured and collected lay within a threetip sagebrush (A. tripartita) bluebunch wheatgrass (Agropyron spicatum) vegetative type. Surrounding topography is undulating and marked by pronounced lava outcrops. Climatic conditions are characterized by hot summers and cold, harsh winters, with an average annual precipitation of $292 \mathrm{~mm}$ (11.5 in.). Most of the moisture falls as rain with May and June receiving the highest precipitation.

Twenty threetip sagebrush and 20 gray horsebrush plants were selected from each of 5 sites during May, 1979. In addition, 50 green rabbitbrush and 50 broom snakeweed plants were selected from a 10-ha a rea in August, 1979. Plants were selected to encompass the size range of plants normally found on the Station, with the exception of very small, young, or seedlings.

On each selected plant, four diameters were measured across the crown at $45^{\circ}$ angles. The height from ground level to the tallest nonflowering stem was also measured (Fig. 1). Many plants have multiple stems arising from below ground level. These were counted for use as an additional variable. Each plant was then severed at ground level and air-dried to a moisture content between $5-10 \%$. Threetip sagebrush and gray horsebrush plants were separated individually into the following fractions: (1) leaves, (2) live twigs $<0.6 \mathrm{~cm}^{1}$, (3) live twigs $0.6-2.5 \mathrm{~cm}$, (4) live twigs $>2.5 \mathrm{~cm}$, (5) dead floral twigs (threetip sagebrush), (6) dead twigs $<0.6 \mathrm{~cm},(7)$ dead twigs $0.6-2.5 \mathrm{~cm}$, and (8) dead twigs $>2.5 \mathrm{~cm}$. For additional predictions the above were combined into: (9) leaves and live twigs $<0.6 \mathrm{~cm}$, (10) total of all live twigs, (11) total live material, (12) total of all dead twigs excluding floral twigs, (13) total live and dead twigs, and (14) total plant. Green rabbitbrush and broom snakeweed were not separated into fractions because of their generally small size.

Diameter and height measurements were used to calculate circumference, surface area, and volume for the following shapes: right cylinder, elliptical cylinder, polygonal cylinder (Fig. 1), sphere, average radius oblate or prolate spheroid, and maximum radius oblate or prolate spheroid. Formulas used in these calculations are given in Table 1 . If the the average or maximum radius was less than height, an oblate spheroid was calculated, and if

\footnotetext{
These twig sizes were chosen because of their importance in fire modeiling. I wig sized $<0.6 \mathrm{~cm}(0.25 \mathrm{in}$ ), $0.6-2.5(0.25-1.00 \mathrm{in})$, and $>2.5(1.00 \mathrm{in})$ represent size classes used to characterize the time-lag constant i.e., their ability to respond to humidity by absorbing and desorbing moisture (Fosberg, 1970). The size classes, in the order above, are called the 1 hour $(\mathrm{h}), 10 \mathrm{~h}$, and $100 \mathrm{~h}$ classes.
} 
Table 1. Numbering system used to identify the independent variable.

\begin{tabular}{lccc}
\hline \hline Shape & Circumferncel & Surface area $^{2}$ & Volume $^{3}$ \\
\hline Right cylinder & 1 & 6 & 11 \\
Elliptical cylinder & 2 & 7 & 12 \\
Sphere & 3 & 8 & 13 \\
Polygonal cylinder & 4 & 9 & 14 \\
Spheroid (oblate or prolate) & 5 & 10 & 15 \\
\hline
\end{tabular}

'Circumference expressed in $\mathrm{cm}$

'Surface area expressed as $\mathrm{cm}^{2} / 100$

${ }^{3}$ Volume expressed as $\mathrm{m}^{3} \Omega 1000$

greater than height, a prolate spheroid was calculated. Fifteen independent variables were generated. In addition, for the total plant weight category, volume based on length $X$ width, $X$ height (as used by Uresk et al. 1977, and Green and Flinders, 1980) was tested as a variable.

Each dependent-independent variable pair was fitted by least squares using the regression form for the following arithmetic models:

\begin{tabular}{l} 
Arithmetic Form \\
\hline$Y=a+b X$ \\
$Y=a e^{\mathrm{bX}}$ \\
$Y=a x^{\mathrm{b}}$ \\
$Y=a h C^{\mathrm{b}}$ \\
$Y=a h^{\mathrm{b}} C^{c}$
\end{tabular}

\begin{tabular}{l} 
Regression Form \\
\hline$Y=a+b X$ \\
$\ln Y=\ln a+b X$ \\
$\ln Y=\ln a+\ln X$ \\
$(\ln Y-\ln H)=\ln a+b \ln C$ \\
$\ln Y=\ln a+b \ln h+c \ln C$
\end{tabular}

where $Y=$ weight (g) of a plant fraction, $x=1$ of 15 independent variables (Table 1$), H=$ height $(\mathrm{cm}), C=$ circumference $(\mathrm{cm})$, and $a$ and $b, c$ a re the $Y$-intercept and slopes, respectively. Models 4 and 5 used the circumference based on a circle, while 6 and 7 were based on the circumference of an ellipse.

The Standard deviation about the regression line $\left(S_{\mathbf{y} . \mathbf{x}}\right)$ were used to compare the different regressions. For models $2-7$, the $S_{y . x}$ was computed as:

$$
S_{\mathrm{y} \cdot \mathrm{x}}=\frac{\left(Y-Y_{\mathrm{e}}\right)^{2}}{(n-p)}
$$

where $Y=$ actual weight, $Y_{\mathrm{e}}=$ estimated weight from regression, $\boldsymbol{n}$ $=$ number of observations in the data set, and $p=$ the number of variables in the model. Several other models and independent variables were examined (containing more than 1 independent variable including numbers of stems) but were excluded because none showed improvement over the models given above.

\section{Results}

Threetip sagebrush plants are generally smaller in size than big sagebrush species. Threetip sagebrush plants for this study ranged in average diameter and height from 20 to $109 \mathrm{~cm}$ and 21 to $67 \mathrm{~cm}$, with means of 52 and $45 \mathrm{~cm}$, respectively (Table 2). These ranges
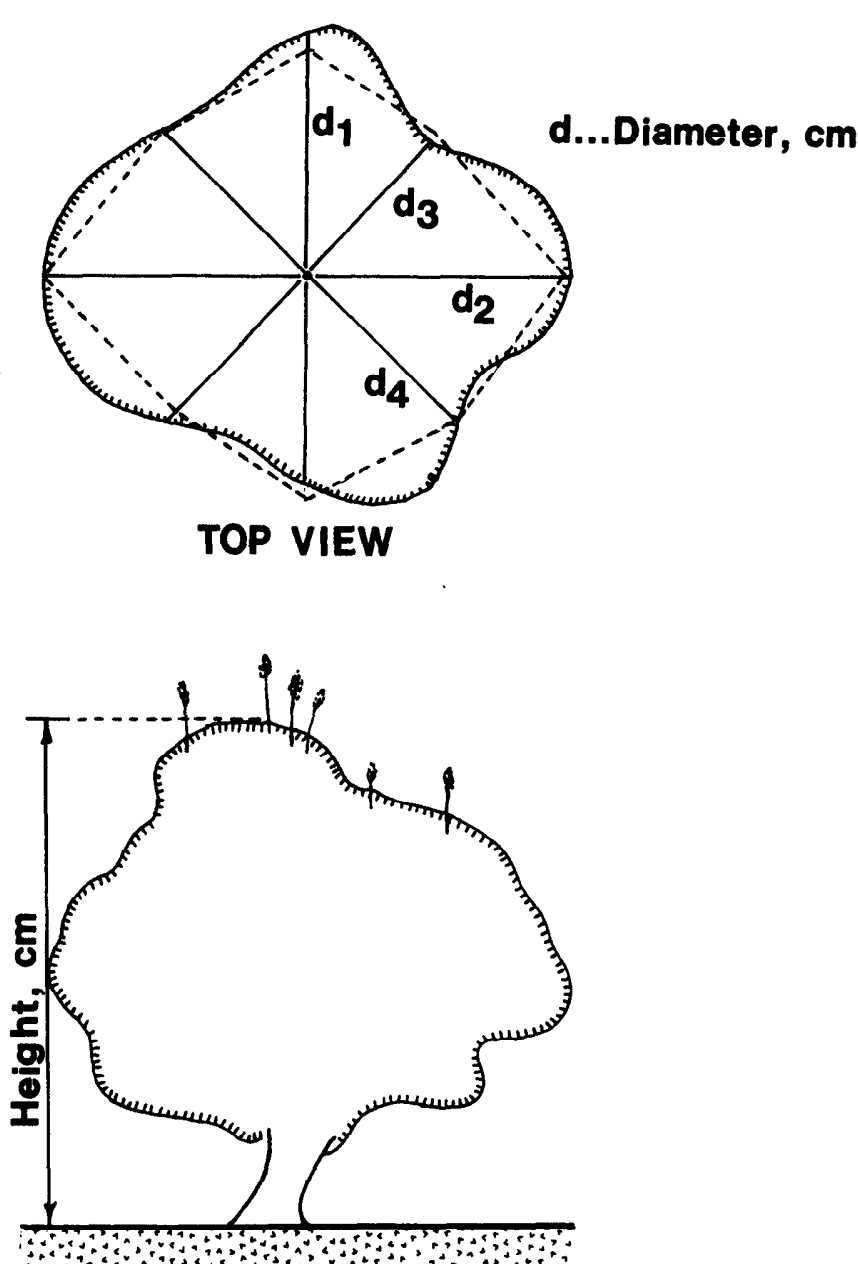

SIDE VIEW

Fig. 1. Top and side views of a sagebrush plant showing measurement technique used and derivation of polygonal cylinder.

are less than those reported for Wyoming big sagebrush in eastern Oregon (Rittenhouse and Sneva 1977) and for basin and mountain big sagebrush in Idaho (Harniss and Murray 1976). Total plant weights of threetip sagebrush averaged $258 \mathrm{~g}$ and varied from 17 to $1120 \mathrm{~g}$ (Table 3).

Gray horsebrush, green rabbitbrush, and broom snakeweed plants are smaller than threetip sagebrush. Average heights, diameters, and weights are given in Tables 2 and 3. Total average plant weights for these species, in the order given, were 138,59 , and 4 grams per plant.

In most cases, either volume or surface area was a better predictor of biomass than circumference alone when models 1-3 were

Table 2. Height and diameter ranges, by site, for threetip sagebrush, gray horsebrush, green rabbitbrush, and broom snakeweed plants harvested at U.S. Sheep Experiment Station, Dubois, Ida. (1978).

\begin{tabular}{|c|c|c|c|c|c|c|c|c|c|c|c|c|}
\hline \multirow[b]{3}{*}{ Site } & \multicolumn{6}{|c|}{ Threetip sagebrush } & \multicolumn{6}{|c|}{ Gray horsebrush } \\
\hline & \multicolumn{3}{|c|}{ Height (cm) } & \multicolumn{3}{|c|}{ Diameter $(\mathrm{cm})$} & \multicolumn{3}{|c|}{ Height $(\mathrm{cm})$} & \multicolumn{3}{|c|}{ Diameter $(\mathrm{cm})$} \\
\hline & Min. & Mean & Max. & Min. & Mean & Max. & Min. & Mean & Max. & Min. & Mean & Max. \\
\hline $\begin{array}{l}1 \\
2 \\
3 \\
4 \\
5\end{array}$ & $\begin{array}{l}28 \\
21 \\
25 \\
22 \\
35\end{array}$ & $\begin{array}{l}45.2 \\
43.4 \\
45.1 \\
41.0 \\
49.6\end{array}$ & $\begin{array}{l}67 \\
56 \\
65 \\
52 \\
63\end{array}$ & $\begin{array}{l}20.5 \\
22.5 \\
21.2 \\
28.2 \\
30.2\end{array}$ & $\begin{array}{l}52.2 \\
48.1 \\
53.8 \\
52.0 \\
54.4\end{array}$ & $\begin{array}{r}107.0 \\
109.0 \\
91.8 \\
99.8 \\
85.0\end{array}$ & $\begin{array}{l}21 \\
20 \\
24 \\
23 \\
23\end{array}$ & $\begin{array}{l}31.2 \\
35.4 \\
35.8 \\
34.0 \\
35.5\end{array}$ & $\begin{array}{l}46 \\
52 \\
50 \\
53 \\
54\end{array}$ & $\begin{array}{l}19.5 \\
20.5 \\
25.2 \\
25.5 \\
12.2\end{array}$ & $\begin{array}{l}40.9 \\
41.5 \\
41.5 \\
40.5 \\
46.2\end{array}$ & $\begin{array}{l}90.2 \\
65.2 \\
65.2 \\
57.8 \\
83.0\end{array}$ \\
\hline \multirow[t]{2}{*}{$1-5$} & 21 & 44.9 & $\begin{array}{c}67 \\
\text { Green } \\
\end{array}$ & $\begin{array}{c}20.5 \\
\text { tbrush }\end{array}$ & 52.1 & 109.0 & 20 & 34.4 & $\begin{array}{c}54 \\
\text { Broom } \\
\end{array}$ & $\begin{array}{c}12.2 \\
\text { eweed }\end{array}$ & 42,1 & 90.2 \\
\hline & 11 & 33.1 & 76 & 9.0 & 33.3 & 61.2 & 9 & 17.0 & 27 & 8.5 & 18.4 & 31.2 \\
\hline
\end{tabular}


used based on the $S_{\mathrm{y} . \mathrm{x}}$. The exponential model (2) fit the data poorly compared to the other models. Although, it was found that $R$ values were generally increased using models $2-7$, the $S_{y . x}$ values were often lower with model 1.

The correlations between plant weight fractions and various independent variables were generally greater for threetip sagebrush than horsebrush (Table 3 ). However, the ability to predict biomass of dead twigs was somewhat better in gray horsebrush than threetip sagebrush. This may be due to the greater proportion of dead wood in horsebrush. The live twig $2.5 \mathrm{~cm}$ and dead twig $0.6-2.5 \mathrm{~cm}$ fractions were poorly related, in both species, to the independent variables used in this study. An estimate of the proportion of dead wood, or number of twigs in that size fraction used as an additional variable, may improve the ability to predict the biomass of that fraction. The dead floral twig fraction of threetip sagebrush was also poorly correlated to these variables. Uresk et al. (1977) found the poorest relationship when predicting the phytomass of flowering stalks compared to other fractions in big sagebrush. Similarly, Mack (1971) and Murray (1975) were unable to develop satisfactory relationships between inflorescence weight and canopy volume for big sagebrush plants.

The different plant shapes used to calculate relationships to weight varied between species and fractions. This suggests that improvement in predicting biomass might be achieved by developing a classification scheme for various plant shapes. In practice, the observer would decide the appropriate shape in the field, take the necessary measurements, and then calculate the area or volume representative of that shape. This approach was applied to some extent by Bentley et al. (1970) and Ludwig et al. (1975).

Flammability increases as the amount of dead stemwood increases. We found threetip sagebrush had a lower ratio of dead to live material $(0.46)$ than gray horsebrush $(0.95)$ shrubs on the average. There was a tendency for the ratio to increase as plant size increased. Uresk et al. (1977) found that only $11 \%$ of the total big sagebrush phytomass was in the deadwood fraction. Murray (1975) found, in southern Idaho, ratios of dead to live were 0.04 , $0.09,0.10$, and 0.27 for big sagebrush stands with average plant ages of $12,24,31$, and 45 years, respectively. In eastern Washington, Mack (1971) found the average ratio of dead:live was 0.09 for big sagebrush plants with ages that ranged from 14 to 29 years. However, Mack's sample size was small and was selected. Apparently, the amount of dead material increases more with age, but size increase irrespective of age may also contribute to greater amounts of deadwood. The fact that many threetip sagebrush and gray horsebrush plants have multiple stems would make a study of this phenomenon more difficult because of the problem of obtaining true ages for such plants. At least with the plants we examined, there is a greater proportion of dead standing material compared to live standing material than in most big sagebrush plants.

The $S_{y . x}$ giving the lowest value was used to select the appropriate model and independent variable for predicting biomass of a species or fraction. These models, variables, coefficients of determinations, $S_{\mathrm{y} . \mathrm{x}}$ 's, $Y$-intercepts, and slopes are given in Table 3. In some cases, a different model was selected when the $Y$-intercept greatly exceeded the minimum biomass for that species or fraction even though the $S_{\mathbf{y} . \mathrm{x}}$ increased slightly.

Green and Flinders (1980) (also at the U.S. Sheep Experiment Station) developed a prediction equation for total plant weight, based on 20 plants, following the measurement technique for Uresk et al. (1977). They computed $R^{2}$ values using model 1 of 0.98 , $0.90,0.67$, and 0.67 , and 0.79 , and we computed $R^{2}$ values of 0.84 , $0.70,0.88$, and 0.82 for threetip sagebrush, gray horsebrush, green rabbitbrush, and broom snakeweed, respectively. We found model 6 increased the $R$ and reduced the sy.x over model 1 for our threetip

Table 3. Statistical data for different fractions for threetip sagebrush, gray horsebrush, green rabbitbrush, and broom snakeweed plants.

\begin{tabular}{|c|c|c|c|c|c|c|c|c|c|c|c|}
\hline & & & nass $(\mathrm{g})$ & & Model & $x$ & & & & & \\
\hline & No. & Min. & Mean & Max. & No. & Var. & $R^{2}$ & $S_{y . x}$ & a & b & $\mathbf{c}$ \\
\hline & & & & & Threet & $\overline{\text { gebrus }}$ & & & & & \\
\hline Leaves & 100 & 4 & 50 & 222 & 3 & 8 & .89 & 15.8 & -.40 & .94 & \\
\hline Leaves \& live twigs $<.6$ & 100 & 12 & 131 & 514 & 1 & 8 & .86 & 37.4 & 12.75 & 1.21 & \\
\hline Live twigs $<.6 \mathrm{~cm}$ & 100 & 7 & 81 & 330 & $6^{1}$ & - & .95 & 29.6 & .00 & .36 & 1.97 \\
\hline Live twigs $.6-2.5 \mathrm{~cm}$ & 99 & 1 & 65 & 350 & 4 & - & .59 & 29.8 & .00 & 1.80 & \\
\hline Live twigs $>2.5 \mathrm{~cm}$ & 26 & 10 & 42 & 184 & 1 & 4 & .09 & 40.2 & 2.31 & .16 & \\
\hline Total live twigs & 100 & 9 & 156 & 616 & 1 & 8 & .88 & 46.9 & -3.76 & 1.63 & \\
\hline Total live plant & 100 & 16 & 206 & 764 & 1 & 8 & .90 & 52.4 & 2.99 & 2.08 & \\
\hline Dead twigs $<.6 \mathrm{~cm}$ & 98 & 1 & 40 & 237 & i & 13 & .81 & 23.0 & .78 & .04 & \\
\hline Dead twigs .6-2.5 cm & 33 & 1 & 15 & 69 & $i$ & 8 & .07 & 15.8 & 8.30 & .05 & \\
\hline Total dead twigs & 98 & 1 & 45 & 318 & 1 & 13 & .74 & 30.4 & 2.45 & .04 & \\
\hline Dead floral parts & 98 & 1 & 8 & 63 & 1 & 14 & .39 & 7.7 & 1.16 & .003 & \\
\hline Total live \& dead twigs & 100 & 9 & 200 & 935 & 6 & - & .94 & 62.7 & .00 & .61 & 1.99 \\
\hline Total plant & 100 & 17 & 258 & 1120 & 6 & - & .95 & 69.5 & .00 & .55 & 1.93 \\
\hline & & & & & Gres & ibbitbs & & & & & \\
\hline Total plant & 50 & 1 & 59 & 272 & 6 & - & .97 & 22.8 & .00 & 1.84 & \\
\hline & & & & & Gra & rsebru & & & & & \\
\hline Leaves & 100 & 2 & 16 & 131 & 1 & 13 & .61 & 10.4 & 4.92 & .02 & \\
\hline Leaves \& live twigs & 100 & 6 & 61 & 361 & 1 & 13 & .87 & 20.7 & 14.06 & .09 & \\
\hline Live twigs $<.6 \mathrm{~cm}$ & 100 & 6 & 45 & 299 & 1 & 13 & .88 & 14.9 & 9.14 & .07 & \\
\hline Live twigs $.6-2.5 \mathrm{~cm}$ & 97 & 1 & 26 & 180 & $i$ & 14 & .60 & 16.2 & 3.33 & .02 & \\
\hline Live twigs $>2.5 \mathrm{~cm}$ & 19 & 9 & 23 & 74 & 1 & 2 & .07 & 17.1 & 5.79 & .10 & \\
\hline Total live twigs & 100 & 3 & 75 & 438 & 6 & - & .90 & 31.1 & .00 & .28 & 2.15 \\
\hline Total live plant & 100 & 6 & 91 & 569 & 6 & - & .92 & 37.8 & .00 & .24 & 2.07 \\
\hline Dead twigs $<.6 \mathrm{~cm}$ & 100 & 1 & 35 & 163 & 7 & - & .80 & 18.9 & .01 & .55 & 2.41 \\
\hline Dead twigs $.6-2.5 \mathrm{~cm}$ & 58 & $i$ & 20 & 400 & 1 & 5 & .01 & 52.9 & -12.47 & .17 & \\
\hline Total dead twigs & 100 & 1 & 47 & 402 & 7 & - & .65 & 46.3 & .00 & 2.32 & .53 \\
\hline Dead floral parts & 0 & - & - & - & - & - & - & - & - & & \\
\hline Total live \& dead twigs & 100 & 5 & 121 & 648 & 6 & - & .91 & 57.7 & .00 & .65 & 2.13 \\
\hline Total plant & 100 & 8 & 138 & 780 & 6 & - & .92 & 61.0 & .00 & .58 & 2.08 \\
\hline & & & & & Broc & nakew & & & & & \\
\hline Total plant & 50 & 1 & 4 & 17 & 6 & - & .92 & 1.2 & .00 & 1.47 & \\
\hline
\end{tabular}

'Models 6 and 7 have (y-intercept) values less than .0001 when shown as .00 
sagebrush and gray horsebrush plants, while model 4 performed similarly for green rabbitbrush and broom snakeweed. We can only speculate on the differences found between Green and Flinders (1980) and our results. We selected 20 plants at each of 5 sites, while Green and Flinders (1980) selected 4 plants from 5 sites. It may be that we encompassed greater variability because of the larger number of plants.

In this study, we did not develop a general model as was done by Harniss and Murray (1976). We sought to determine the best relationship and determine the shape of the height-circumference to weight relationship for each fraction. In every case, the exponent of circumference was greater than the 1.25 reported for big sagebrush leaves by Harniss and Murray (1976). With exception of some live or dead twig fractions, our models accounted for a greater proportion of the total variance than Harniss and Murray (1976). However, they developed their model for big sagebrush by using Matchacurve-3 techniques (Jensen 1973) after grouping weights by height classes, which may account for the lower value.

The time of year when biomass prediction equations are developed for big sagebrush can influence the magnitude of the equation parameters. It has been known for some time that big sagebrush produces enlarged leaves during the spring and sheds these during early summer. This phenomenon was corroborated by Mack (1971), who found peak leaf fall of big sagebrush occurred during early summer. Obviously, equations developed prior to the drop of these ephemeral leaves would result in larger $b$-values than those developed after their fall, because of the greater biomass for essentially the same sized plant. It is not known whether threetip sagebrush has a similar leaf growth and fall pattern to that of big sagebrush. However, these equations can be adjusted to reflect differences in biomass due to time of year or site. Although, we have not tested the application of our equations to new data sets, we believe that the parameters reported can be used for the basic model and for subsequently adjusting the new data sets as described in Harniss and Murray (1976).

\section{Conclusions}

Easily measured crown diameters and heights were successfully used to estimate biomass of various fractions of threetip sagebrush, gray horsebrush, and total biomass of these species and green rabbitbrush and broom snakeweed. Independent variables-based on circumference, surface area, and volume of various plant shapes-used in models of the form $Y=a+b X, Y=a e^{b x}$, and $Y=$ $a x^{b}$ provided satisfactory predictors of biomass in many instances. However, models using height and circumference first derived for estimating biomass of big sagebrush leaves (Harniss and Murray 1976), were more reliable for total weight of the four species than other models and variables tested.

It is believed that further improvement in developing biomass predictors for shrub species may be achieved by (1) deriving surface areas and volumes based on the shapes of individual plants, and (2) including additional independent variables, such as the number of twigs of a certain size and percent of live or dead crown.

\section{Literature Cited}

Attiwill, P.M. 1962. Estimating branch dry weight and leaf area from measurements of branch girth in Eucalyptus. Forest Sci. 8:132-141.

Baskerville, G.L. 1965. Estimation of dry weight of tree components and total standing crop in conifer stands. Ecology 46:867-869.

Bentley, J.R., D.W. Seegrist, and D.A. Blakeman. 1970. A technique for sampling low shrub vegetation by crown volume classes. USDA-Forest Service Res. Note PSW-215. 11 p.

Brown, J.K. 1976. Estimating shrub biomass from basal stem diameters. Canad. J. Forest Res. 6:153-158.

Brown, J.K. 1978. Weight and density of crowns of Rocky Mountain conifers. USDA-Forest Service Res. Pap. INT-197. 56 p.

Burk, J.H., and W.A. Dick-Peddie. 1973. Comparative production of Larrea divaricata Cav. on three geomorphic surfaces in southern New Mexico. Ecology 54:1094-1102.

Chew, R.M., and A.E. Chew. 1965. The primary productivity of a desert shrub Larrea tridentata) community. Ecol. Monog. 35:355-375.

Fosberg, M. 1970. Drying rates of heartwood below fiber saturation. Forest Sci. 16:57-63.

Green, J.S., and J.T. Flinders (1980). Habitat and dietary relationships of the pygmy rabbit. J. Range Manage. 33:136-142.

Harniss, R.o. and R.B. Murray. 1976. Reducing bias in dry leaf weight estimates of big sagebrush. J. Range Manage. 29:430-432.

Jensen, C.E. 1973. Matchacurve-3: multiple component and multidimensional mathematical models for natural resource studies. USDA-Forest Service Res. Pap. INT-146, 42 p.

Kittredge, J. 1944. The estimation of the amount of foliage of trees and stands. J. Forest. 42:905-912.

Ludwig, J.A., J.F. Reynolds, and P.D. Whitson. 1975. Size-biomass relationships of several Chihuahuan desert shrubs. Amer. Midl. Natur. 94:451-461.

Lyon, L.J. 1968. Estimating twig production of serviceberry from crown volumes. J. Wildlife Manage. 32:115-119.

Mack, R.N. 1971. Mineral cycling in Artemisia tridentata. Ph.D. Diss. Washington State Univ., Pullman.

Murray, R.B. 1975. Effect of Artemisia tridentata removal on mineral cycling. Ph.D. Diss. Washington State Univ., Pullman. 190 p.

Pechanec, J.F., and G.D. Pickford. 1937. A weight estimate method for determination of range or pasture production. J. Amer. Soc. Agron. 29:894-904.

Rittenhouse, L.R. and F.A. Sneva. 1977. A technique for estimating big sagebrush production. J. Range Manage. 30:68-70.

Telfer, E.S. 1969. Weight-diameter relationships for 22 woody plant species. Canad. J. Bot. 47:1851-1855.

Tufts, W.P. 1919. Pruning of deciduous fruit trees. Calif. Agric. Exp. Sta. Bull. No. 313.

Uresk, D.W., R.O. Gilbert, and W.H. Rickard. 1977. Sampling big sagebrush for phytomass. J. Range Manage. 30:311-314.

Wakimoto, R.H. and J.W. Menke. 1978. Measuring chaparral fuels. Calif. Agric. October 15-16. 